\title{
Comparisons of Soft Tissue Thickness Measurements in Adult Patients With Various Vertical Patterns
}

\author{
Farklı Vertikal Paternlere Sahip Bireylerde Yumuşak Doku \\ Kalınlıklarının Değerlendirilmesi
}

\author{
Neslihan Seyhan Cezairli
}

Ordu University Faculty of Dentistry, Department of Orthodontics, Ordu, Turkey

\section{Keywords}

Holdaway, soft tissue, divergence, cephalometrics, facial profile, thickness

\section{Anahtar Kelimeler}

Holdaway, yumuşak doku, diverjans, sefalometri, fasiyal profil, kalınlık

Received/Geliş Tarihi : 22.03.2017

Accepted/Kabul Tarihi : 25.05.2017

doi:10.4274/meandros.76376

Address for Correspondence/Yazışma Adresi: Neslihan Seyhan Cezairli MD, Ordu University Faculty of Dentistry, Department of Orthodontics, Ordu, Turkey Phone : +90 4522125011 E-mail : nesli_seyhan_13@hotmail.com ORCID ID: orcid.org/0000-0001-8750-4161

(C) Meandros Medical and Dental Journal, Published by Galenos Publishing House.

This is article distributed under the terms of the Creative Commons Attribution NonCommercial 4.0 International Licence (CC BY-NC 4.0).

\begin{abstract}
Objective: The purposes of this study were to evaluate to study soft tissue facial profile among the different vertical patterns using the Holdaway analysis and the soft tissue thickness measurements.

Materials and Methods: The study sample consisted of 90 patients divided into 3 groups: low angle group (30 patients; mean age, $20.38 \pm 3.76$ years), normal angle group (30 patients; mean age, $19.36 \pm 2.83$ years) and high angle group (30 patients; mean age, $19.44 \pm 2.14$ years). The study sample, comprised a total of 90 patients ( 54 women and 36 men) divided into low-angle, normal-angle and high angle groups based on vertical growth pattern using the SN/GoGn angle (high-angle group $>37^{\circ}$; low-angle group $<27^{\circ}$; and control group or normal angle group 27$37^{\circ}$ ). Facial soft-tissue thickness and Holdaway measurements were analyzed on each radiograph with Image J programme. One-way analysis of variance and post-hoc test (Tukey) were used to compare Holdaway measurements and soft tissue thicknesses among the three groups.

Results: Significant differences among vertical patterns were observed for the 'gnathion', 'menton', 'stomion' and 'inferior sulcus to $\mathrm{H}$ line' when both genders were combined. These measurements were thinner in the high-angle group. Significant differences among vertical patterns were observed for 'gnathion' and 'lower lip to $\mathrm{H}$ line' in women; for 'stomion' and 'nose prominence' in men when examined separately.

Conclusion: Facial soft tissue measurements except some for in high angle group were thinner than in low angle group. All soft tissue measurements were greater except for gnathion in low angle group in men than in women.
\end{abstract}

Öz

Amaç: Bu çalışmanın amacı, Holdaway analizi ve yumuşak doku kalınlık ölçümleri kullanılarak farklı vertikal paternlerde yumuşak doku profilini değerlendirmektir.

Gereç ve Yöntemler: Doksan hastadan oluşan çalışma grubu SN/GoGn açısı kullanılarak vertikal gelişim paternine göre 3 gruba ayrıldı (hiperdiverjan $>37^{\circ}$; hipodiverjan $<27^{\circ}$; ve kontrol grup veya normodiverjan $27-37^{\circ}$ ); hipodiverjan (30 hasta; ortalama yaş, 20,38 $\pm 3,76$ yıl), normodiverjan (30 hasta; ortalama yaş, 19,36 $\pm 2,83$ yıl) ve hiperdiverjan (30 hasta; ortalama yaş, 19,44 2,14 yıl). Yüz yumuşak doku kalınlık ölçümleri ve Holdaway ölçümleri her bir radyograf üzerinde Image J programı ile yapıldı. Üç grup arasında yumuşak doku ve Holdaway ölçümleri arasındaki fark, one-way analysis of variance ve post-hoc test (Tukey) ile değerlendirildi.

Bulgular: Vertikal paternler arasında 'gnathion', 'menton', 'stomion' and 'inferior sulcus to $\mathrm{H}$ line' ölçümlerinde, cinsiyet ayrımı yapılmaksızın değerlendirildiğinde istatistiksel olarak önemli bir fark bulundu. Cinsiyet ayrımı yapıldığında ise kadınlarda 'gnathion' and 'lower lip to H line' ölçümlerinde, erkeklerde 'stomion' and 'nose prominence' ölçümlerinde istatistiksel olarak anlamlı fark bulundu. 
Sonuç: Sadece hiperdiverjandaki bazı ölçümler hariç tüm yumuşak doku kalınlık ölçümleri hipodiverjan en az bulundu. 'Gnathion' ölçümü hariç diğer tüm yumuşak doku ölçümleri ise erkeklerde kadınlardan daha fazla bulundu.

\section{Introduction}

It is generally accepted that there is a relationship between occlusal forces and facial morphology. Three basic types of facial morphology exist: short face, average, and long face. Long face has excessive vertical facial growth and typically associated with anterior open bite and an increased maxillary/mandibular planes angle, sella-nasion/mandibular plane angle and gonial angle (1). Short face has decreased vertical growth and typically accompanied by deep bite, reduced facial heights, and decreased SN/mandibular plane angle (2). Average face has normal vertical pattern angles (3). The relationship between bite force and craniofacial morphology has been studied (4). Average face subjects have higher bite force in molar region as compared with long face subjects, while short face subjects had still higher maximum forces than the normal face subjects (4).

The changes that occur in the soft-tissue profile during orthodontic treatment have played a significant role in the diagnosis and treatment planning process (5). Facial harmony and balance are determined by the facial skeleton and its soft tissue drape. Most previous studies were routinely used to evaluate the position of the teeth in relation to the skeletal components. However, sporadic attempts were made to include an element of soft tissue profile assessment, such as Ricketts (6) esthetic plane, Holdaway (7) analysis and Burstone's (8) soft tissue analysis.

Previous studies have studied facial soft tissue thickness in Japanese children having different skeletal classes $(9,10)$. Utsuno et al. (9) indicated that measurements differed among these various classes. Several studies have made similar measurements in the Turkish population (11-13). Bascifci et al. (11) made a study to determine Holdaway soft tissue norms in Anatolian Turkish adults and found significant differences between genders for soft tissue chin thickness and upper lip thickness. Kamak and Celikoglu (14) found that soft tissue thickness at all regions was higher in men than in women.

The purposes of this study was to evaluate the soft tissue facial profiles among the different vertical patterns using the Holdaway analysis and the soft tissue thickness measurements, compare all values with the Holdaway soft-tissue norms of Anatolian Turkish adults and to determine any sexual differences between the soft tissue facial profile of men and women in each vertical group.

\section{Materials and Methods}

This study was designed to evaluate the differences in soft-tissue characteristics as determined by the Holdaway soft-tissue analysis of orthodontic patients and to determine the soft tissue thickness of orthodontic patients with different vertical growth patterns. This study was approved by the Ethics Committee of Karadeniz Technical University Faculty of Medicine (ethics committee approval no: 2013/91). A total of 90 patients ( 36 boys and 54 girls), referred to the Department of Orthodontics at the Karadeniz Teknik University Faculty of Dentistry, were included in this study. The study sample, comprised a total of 90 patients aged $20-26$ years divided into low-angle, normal-angle and high angle groups based on vertical growth pattern using the SN/GoGn angle (highangle group $>37^{\circ}$; low-angle group $<27^{\circ}$; and control group or normal angle group $27-37^{\circ}$ ). The images used in the present study were part of the diagnostic records collected due to dental treatment need. Lateral cephalometric radiographs were taken from all patients. The age of the subjects ranged between 20-26 years, with a mean age of $20.38 \pm 3.76$ years, $19.36 \pm 2.83$ years and $19.44 \pm 2.14$ years in groups 1,2 and 3, respectively. Gender and age distributions are shown in Table 1 . All subjects were selected on the basis of the following criteria:

- Balanced facial profiles with competent lips,

- No history of previous orthodontic treatment,

- No congenitally missing teeth,

- Subjects with skeletal Class I malocclusions $\left(1^{\circ}\right.$ $<$ ANB $<5^{\circ}$ ),

- Subjects with different vertical relationships (SN/ GoGn $=32 \pm 6^{\circ}$ ),

- Nongrowing patients.

The subjects were divided into three groups based on $\mathrm{SN} / \mathrm{GoG}^{\circ}$ angle. All patients had skeletal Class I $\left(1^{\circ}<\mathrm{ANB}<5^{\circ}\right)$ malocclusions. 
- Group 1 included 30 hipodiverjant subjects,

- Group 2 included 30 normodiverjant subjects,

- Group 3 included 30 hiperdiverjant subjects.

The radiographs were analyzed by the same researcher. Eighteen linear and two angular measurements were analyzed on each radiograph with Image J software. The landmarks were located according to the definition provided by Holdaway (15). The following measurements were used (Figures 1 and 2):

- $\mathrm{H}$ line: Tangent drawn from the tip of the chin to the upper lip;

- Soft tissue facial angle (STA): The downward and inner angle formed at a point where the sella-nasion line crosses the soft tissue and a line combining the suprapogonion with the Frankfort horizontal plane;

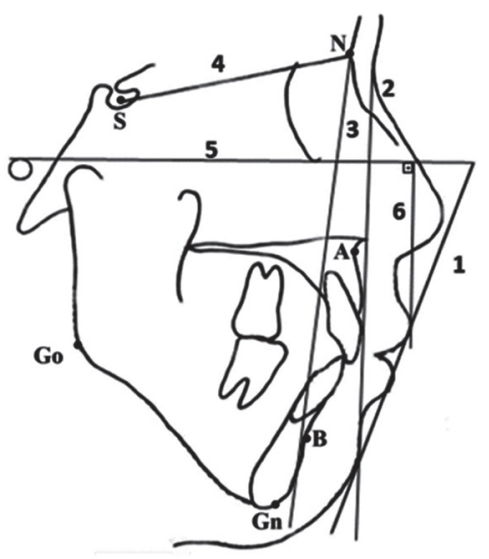

Figure 1. The planes used: (1) $\mathrm{H}$ line or harmony line: drawn tangent to the soft tissue chin and the upper lip. (2) Soft tissue facial line: drawn from soft tissue nasion to the point on the soft tissue chinoverlying Ricketts suprapogonion. (3) Hard tissue facial plane. (4) Sella-nasion line. (5) Frankfort horizontal plane. (6) A line running at a right angle to the Frankfort plane down tangent to the vermilion

Table 1. Comparison of the demographic variables among different vertical patterns

\begin{tabular}{|l|l|l|l|l|l|} 
& N & $\begin{array}{l}\text { Female/ } \\
\text { Male }\end{array}$ & $\begin{array}{l}\text { Mean Age } \\
\text { (Years) }\end{array}$ & ANB $^{\circ}$ & SN/GoGn \\
\hline High-angle group & 30 & $19 / 11$ & $19.44 \pm 2.14$ & $3.08 \pm 1.39$ & $39.66 \pm 2.14$ \\
\hline Low-angle group & 30 & $18 / 12$ & $20.38 \pm 3.76$ & $2.63 \pm 1.76$ & $24.72 \pm 2.05$ \\
\hline $\begin{array}{l}\text { Normal-angle } \\
\text { group }\end{array}$ & 30 & $17 / 13$ & $19.36 \pm 2.83$ & $2.75 \pm 1.05$ & $31.07 \pm 2.37$ \\
\hline Total & 90 & $54 / 36$ & & & \\
\hline$p$ & & & NS & & \\
\hline $\begin{array}{l}\text { NS: Not significant, ANB: Angle between NA and NB lines, SN/GoGn: Angle } \\
\text { between SN and GoGn lines }\end{array}$ \\
\hline
\end{tabular}

\begin{tabular}{|c|c|c|c|c|}
\hline Measurements & Group & Gender & Mean \pm SD & $p$ \\
\hline \multirow[t]{6}{*}{ Pogonion } & Group 1 & Female & $10.7 \pm 1.87$ & 0.161 \\
\hline & & Male & $11.71 \pm 1.90$ & \\
\hline & Group 2 & Female & $10.36 \pm 1.66$ & $0.015^{*}$ \\
\hline & & Male & $12.02 \pm 1.81$ & \\
\hline & Group 3 & Female & $10.29 \pm 1.76$ & $0.037^{*}$ \\
\hline & & Male & $11.94 \pm 2.34$ & \\
\hline \multirow[t]{6}{*}{ Gnathion } & Group 1 & Female & $8.95 \pm 2.60$ & 0.763 \\
\hline & & Male & $8.69 \pm 1.87$ & \\
\hline & Group 2 & Female & $7.45 \pm 1.37$ & 0.072 \\
\hline & & Male & $8.42 \pm 1.43$ & \\
\hline & Group 3 & Female & $6.70 \pm 1.88$ & 0.264 \\
\hline & & Male & $7.41 \pm 1.01$ & \\
\hline \multirow[t]{6}{*}{ Menton } & Group 1 & Female & $7.81 \pm 2.03$ & 0.255 \\
\hline & & Male & $8.62 \pm 1.58$ & \\
\hline & Group 2 & Female & $6.65 \pm 1.11$ & 0.058 \\
\hline & & Male & $7.66 \pm 1.66$ & \\
\hline & Group 3 & Female & $6.52 \pm 1.84$ & 0.121 \\
\hline & & Male & $7.59 \pm 1.61$ & \\
\hline \multirow[t]{6}{*}{ Glabella } & Group 1 & Female & $5.52 \pm 0.95$ & 0.393 \\
\hline & & Male & $5.79 \pm 0.57$ & \\
\hline & Group 2 & Female & $5.39 \pm 0.73$ & 0.154 \\
\hline & & Male & $5.82 \pm 0.86$ & \\
\hline & Group 3 & Female & $5.34 \pm 0.79$ & 0.224 \\
\hline & & Male & $5.84 \pm 1.42$ & \\
\hline \multirow[t]{6}{*}{ Nasion } & Group 1 & Female & $5.58 \pm 6.67$ & $0.025^{*}$ \\
\hline & & Male & $6.67 \pm 1.38$ & \\
\hline & Group 2 & Female & $5.25 \pm 0.94$ & $0.011^{*}$ \\
\hline & & Male & $6.28 \pm 1.11$ & \\
\hline & Group 3 & Female & $5.24 \pm 0.99$ & 0.117 \\
\hline & & Male & $5.89 \pm 1.15$ & \\
\hline \multirow[t]{6}{*}{ Rhinion } & Group 1 & Female & $1.54 \pm 0.40$ & $0.033^{*}$ \\
\hline & & Male & $2.18 \pm 1.10$ & \\
\hline & Group 2 & Female & $1.51 \pm 0.38$ & 0.019* \\
\hline & & Male & $1.92 \pm 0.51$ & \\
\hline & Group 3 & Female & $1.31 \pm 0.43$ & $0.016^{*}$ \\
\hline & & Male & $1.77 \pm 0.52$ & \\
\hline \multirow[t]{6}{*}{ Subnasale } & Group 1 & Female & $14.08 \pm 1.47$ & $0.001^{* * *}$ \\
\hline & & Male & $16.77 \pm 2.32$ & \\
\hline & Group 2 & Female & $5.25 \pm 0.94$ & $0.001^{* * *}$ \\
\hline & & Male & $6.28 \pm 1.11$ & \\
\hline & Group 3 & Female & $14.03 \pm 1.97$ & $0.001 * * *$ \\
\hline & & Male & $16.77 \pm 1.67$ & \\
\hline \multirow[t]{5}{*}{ Stomion } & Group 1 & Female & $4.63 \pm 1.70$ & $0.001 * * *$ \\
\hline & & Male & $6.90 \pm 1.55$ & \\
\hline & Group 2 & Female & $3.56 \pm 1.49$ & $0.005^{* *}$ \\
\hline & & Male & $5.35 \pm 1.73$ & \\
\hline & Group 3 & Female & $4.06 \pm 1.86$ & 0.949 \\
\hline
\end{tabular}




\begin{tabular}{|c|c|c|c|c|}
\hline & & Male & $4.11 \pm 1.33$ & \\
\hline \multirow[t]{6}{*}{ Labrale inferior } & Group 1 & Female & $12.55 \pm 1.88$ & $0.001 * * *$ \\
\hline & & Male & $15.14 \pm 1.95$ & \\
\hline & Group 2 & Female & $11.47 \pm 2.06$ & $0.000 * * *$ \\
\hline & & Male & $14.47 \pm 1.23$ & \\
\hline & Group 3 & Female & $12.10 \pm 1.24$ & $0.006 * *$ \\
\hline & & Male & $13.80 \pm 1.88$ & \\
\hline \multirow[t]{6}{*}{ Labiomentale } & Group 1 & Female & $10.30 \pm 1.06$ & 0.240 \\
\hline & & Male & $10.88 \pm 1.55$ & \\
\hline & Group 2 & Female & $10.05 \pm 1.60$ & 0.058 \\
\hline & & Male & $11.09 \pm 1.15$ & \\
\hline & Group 3 & Female & $10.28 \pm 1.40$ & $0.013 *$ \\
\hline & & Male & $11.63 \pm 1.26$ & \\
\hline \multirow{6}{*}{$\begin{array}{l}\text { Soft-tissue } \\
\text { facial angle }\end{array}$} & Group 1 & Female & $84.83 \pm 21.48$ & 0.392 \\
\hline & & Male & $90.29 \pm 3.19$ & \\
\hline & Group 2 & Female & $88.60 \pm 2.65$ & 0.695 \\
\hline & & Male & $88.20 \pm 2.83$ & \\
\hline & Group 3 & Female & $88.44 \pm 2.56$ & 0.356 \\
\hline & & Male & $87.44 \pm 3.23$ & \\
\hline \multirow[t]{6}{*}{$\mathrm{H}$ angle } & Group 1 & Female & $12.03 \pm 5.91$ & 0.575 \\
\hline & & Male & $13.26 \pm 5.69$ & \\
\hline & Group 2 & Female & $12.52 \pm 2.80$ & $0.016^{*}$ \\
\hline & & Male & $15.51 \pm 3.57$ & \\
\hline & Group 3 & Female & $14.68 \pm 3.85$ & 0.576 \\
\hline & & Male & $15.44 \pm 2.84$ & \\
\hline \multirow{6}{*}{$\begin{array}{l}\text { Nose } \\
\text { prominence }\end{array}$} & Group 1 & Female & $14.63 \pm 3.74$ & 0.927 \\
\hline & & Male & $14.73 \pm 1.59$ & \\
\hline & Group 2 & Female & $15.31 \pm 2.68$ & 0.148 \\
\hline & & Male & $13.89 \pm 2.48$ & \\
\hline & Group 3 & Female & $14.69 \pm 2.42$ & 0.008 \\
\hline & & Male & $16.53 \pm 3.08$ & \\
\hline \multirow{6}{*}{$\begin{array}{l}\text { Soft-tissue } \\
\text { subnasale to } \\
\text { H line }\end{array}$} & Group 1 & Female & $3.08 \pm 1.74$ & 0.471 \\
\hline & & Male & $3.68 \pm 2.76$ & \\
\hline & Group 2 & Female & $2.56 \pm 1.59$ & 0.088 \\
\hline & & Male & $3.89 \pm 2.51$ & \\
\hline & Group 3 & Female & $3.49 \pm 2.29$ & 0.126 \\
\hline & & Male & $4.75 \pm 1.72$ & \\
\hline \multirow{6}{*}{$\begin{array}{l}\text { Inferior sulcus } \\
\text { to } \mathrm{H} \text { line } \\
\end{array}$} & Group 1 & Female & $4.50 \pm 1.87$ & 0.096 \\
\hline & & Male & $5.80 \pm 2.23$ & \\
\hline & Group 2 & Female & $4.58 \pm 1.54$ & 0.340 \\
\hline & & Male & $5.15 \pm 1.66$ & \\
\hline & Group 3 & Female & $3.61 \pm 1.51$ & 0.485 \\
\hline & & Male & $4.00 \pm 1.31$ & \\
\hline $\begin{array}{l}\text { Lower lip to } \mathrm{H} \\
\text { line }\end{array}$ & Group 1 & Female & $1.26 \pm 0.86$ & 0.225 \\
\hline
\end{tabular}

- Lower lip to $\mathrm{H}$ line (LLH): The measurement of the lower lip to the $\mathrm{H}$ line;

- $\mathrm{H}$ angle: The angle formed between the softtissue facial plane line and the $\mathrm{H}$ line;

- Skeletal profile convexity (SPC): The dimension between point $A$ and facial line;

- Nose prominence (NP): The dimension between the tip of the nose and a perpendicular line drawn to the Frankfort plane from the vermillion;

- Soft tissue subnasale (Sn) to $\mathrm{H}$ line: The distance from $\mathrm{Sn}$ to $\mathrm{H}$ line;

\begin{tabular}{|c|c|c|c|c|}
\hline & & Male & $0.88 \pm 0.74$ & \\
\hline & Group 2 & Female & $0.54 \pm 0.54$ & 0.075 \\
\hline & & Male & $1.11 \pm 1.12$ & \\
\hline & Group 3 & Female & $1.14 \pm 0.88$ & 0.646 \\
\hline & & Male & $1.29 \pm 0.74$ & \\
\hline \multirow{6}{*}{$\begin{array}{l}\text { Upper-lip } \\
\text { thickness }\end{array}$} & Group 1 & Female & $10.55 \pm 1.93$ & $0.008^{* *}$ \\
\hline & & Male & $12.45 \pm 1.47$ & \\
\hline & Group 2 & Female & $9.54 \pm 2.41$ & $0.000 * * *$ \\
\hline & & Male & $12.83 \pm 1.47$ & \\
\hline & Group 3 & Female & $9.80 \pm 1.45$ & $0.001 * * *$ \\
\hline & & Male & $11.80 \pm 1.57$ & \\
\hline \multirow{6}{*}{$\begin{array}{l}\text { Basic upper-lip } \\
\text { thickness }\end{array}$} & Group 1 & Female & $12.65 \pm 1.64$ & $0.004 * *$ \\
\hline & & Male & $14.82 \pm 2.11$ & \\
\hline & Group 2 & Female & $11.38 \pm 1.86$ & $0.000 * * *$ \\
\hline & & Male & $14.76 \pm 1.47$ & \\
\hline & Group 3 & Female & $11.57 \pm 1.73$ & $0.002 * *$ \\
\hline & & Male & $14.14 \pm 2.40$ & \\
\hline \multirow{6}{*}{$\begin{array}{l}\text { Upper-lip sulcus } \\
\text { depth }\end{array}$} & Group 1 & Female & $1.44 \pm 1.29$ & 0.644 \\
\hline & & Male & $1.67 \pm 1.29$ & \\
\hline & Group 2 & Female & $0.85 \pm 0.69$ & 0.058 \\
\hline & & Male & $1.48 \pm 1.05$ & \\
\hline & Group 3 & Female & $1.26 \pm 1.07$ & 0.821 \\
\hline & & Male & $1.34 \pm 0.51$ & \\
\hline \multirow{6}{*}{$\begin{array}{l}\text { Skeletal profile } \\
\text { convexity }\end{array}$} & Group 1 & Female & $1.65 \pm 1.06$ & 0.281 \\
\hline & & Male & $2.23 \pm 1.82$ & \\
\hline & Group 2 & Female & $1.53 \pm 0.96$ & 0.338 \\
\hline & & Male & $1.96 \pm 1.44$ & \\
\hline & Group 3 & Female & $1.96 \pm 1.32$ & 0.462 \\
\hline & & Male & $2.36 \pm 1.53$ & \\
\hline
\end{tabular}




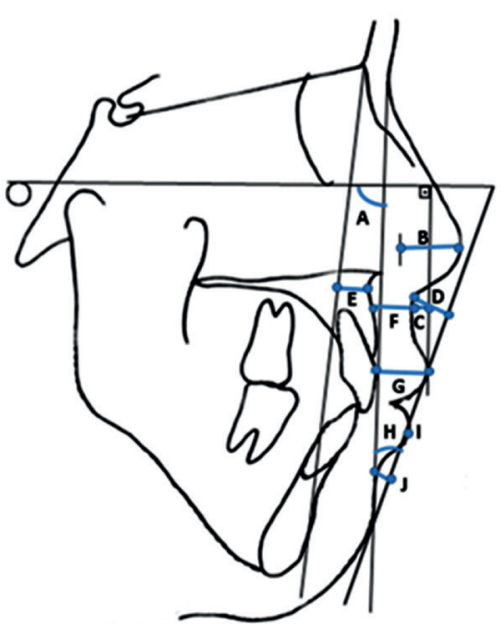

Figure 2. The angular and linear measurements: (A) Soft tissue facial angle: The inner angle formed by the intersection of soft tissue nasion-soft tissue suprapogonion line with the Frankfort horizontal plane. (B) Nose prominence: The distance from a line perpendicular to Frankfort horizontal and running tangent to the vermilion border of the upper lip to the tip of the nose. (C) Superior sulcus depth: Measured to a perpendicular to Frankfort and tangent to the vermilion border to the upper lip. (D) Soft tissue subnasale to $\mathrm{H}$ line: The distance from subnasale to $\mathrm{H}$ line. (E) Skeletal profile convexity: Measurement from point $A$ to the hard tissue line Na-Pog. (F) Basic upper lip thickness: The distance from a point about $3 \mathrm{~mm}$ below point A to the drape of the upper lip. (G) Upper lip thickness: The distance from the labial surface of upper incisors to the vermilion border of the upper lip. $(\mathrm{H}) \mathrm{H}$ angle: Angular measurement of the $\mathrm{H}$ line to the soft tissue facial plane. (I) Lower lip to $\mathrm{H}$ line: The distance from the lower lip to $\mathrm{H}$ line. $(\mathrm{J})$ Inferior sulcus to the $\mathrm{H}$ line: Measured at the point of greatest incurvation between the vermilion border of the lower lip and the soft tissue chin and is measured to the $\mathrm{H}$ line
- Upper lip sulcus depth (USD): The measurement between the upper lip sulcus and a perpendicular line drawn from the vermillion to the Frankfort plane;

- Inferior sulcus to the $\mathrm{H}$ line (lower lip sulcus depth) (ISH): The measurement at the point of greatest convexity between the vermillion border of the lower lip and the $\mathrm{H}$ line;

- Basic upper-lip thickness (BULT): The dimension measured approximately three $\mathrm{mm}$ below point $A$ and the drape of the upper lip;

- Upper-lip thickness (ULT): The dimension between the vermillion point and the labial surface of the upper incisor;

- Pogonion (Pog): Length between bony Pog and its horizontal projection ( $\left.\mathrm{Pog}^{\prime}\right)$ over the vertical passing through soft tissue pogonion.

- Gnathion (Gn): Distance between bony $G n$ and soft tissue (Gn').

- Menton (Me): Distance between bony Me and its vertical projection ( $\mathrm{Me}^{\prime}$ ) on the horizontal passing through soft tissue menton.

- Glabella (G): Length between bony $G$ and its horizontal projection $\left(G^{\prime}\right)$ over the vertical passing through soft tissue glabella.

- Nasion (N): Length between bony $\mathrm{N}$ and its horizontal projection $\left(\mathrm{N}^{\prime}\right)$ over the vertical passing through soft tissue nasion.

- Rhinion (Rhi): Length between bony Pog (Rhi) and its horizontal projection (Rhi') over the vertical passing through soft tissue Rhi.

Table 3. Comparison of the Holdaway measurements among the groups

\begin{tabular}{|c|c|c|c|c|c|c|}
\hline & & & Group 1 & Group 2 & Group 3 & \\
\hline & $\begin{array}{l}\text { Anatolian Turkish } \\
\text { norms }\end{array}$ & Holdaway norms & Mean \pm SD & Mean \pm SD & Mean \pm SD & p \\
\hline STA & $87.31 \pm 8.84$ & $91 \pm 7$ & $87.02 \pm 16.78$ & $88.41 \pm 2.65$ & $88.08 \pm 2.81$ & 0.849 \\
\hline $\mathrm{NP}, \mathrm{mm}$ & $18.74 \pm 3.59$ & 14 to 24 & $14.67 \pm 3.03$ & $14.60 \pm 2.66$ & $15.36 \pm 2.78$ & 0.511 \\
\hline USD, mm & $2.97 \pm 1.53$ & 3 (1 to 4$)$ & $1.53 \pm 1.28$ & $1.19 \pm 0.97$ & $1.29 \pm 0.89$ & 0.448 \\
\hline STSH, mm & $5.12 \pm 3.33$ & $5 \pm 2$ & $3.32 \pm 2.18$ & $3.27 \pm 2.20$ & $3.95 \pm 2.16$ & 0.406 \\
\hline $\mathrm{SPC}, \mathrm{mm}$ & $-0.21 \pm 2.31$ & 0 & $1.88 \pm 1.41$ & $1.73 \pm 1.17$ & $2.11 \pm 1.39$ & 0.530 \\
\hline BULT, mm & $16.64 \pm 2.43$ & 15 & $13.52 \pm 2.10$ & $12.84 \pm 2.35$ & $12.51 \pm 2.33$ & 0.221 \\
\hline ULT, mm & $13.96 \pm 2.7$ & 13 to 14 & $11.31 \pm 1.98$ & $11.02 \pm 2.59$ & $10.53 \pm 1.76$ & 0.375 \\
\hline $\mathrm{H}$ angle & $13.75 \pm 3.01$ & 10 (7 to 14$)$ & $12.52 \pm 5.76$ & $13.92 \pm 3.44$ & $14.96 \pm 3.48$ & 0.100 \\
\hline LLH, mm & $0.03 \pm 1.91$ & 0 to 0.5 ( 1 to 2 ) & $1.11 \pm 0.83$ & $0.79 \pm 0.86$ & $1.20 \pm 0.82$ & 0.139 \\
\hline $\mathrm{ISH}, \mathrm{mm}$ & $6.2 \pm 2.3$ & No norms & $5.02 \pm 2.08$ & $4.80 \pm 1.57$ & $3.75 \pm 1.43$ & $0.012^{*}$ \\
\hline
\end{tabular}


- Subnasale (Sn): The distance between point A and subnasale.

- Stomion (Sto): The shortest distance between the upper incisor and the attachment points of the upper and lower lip.

- Labrale inferior (Li): The distance between infradentale and the vermilion border of the lower lip;

- Labiomental (Labm): The distance between point $B$ and the deepest point of the Labm crease.

Descriptive statistics (mean and standard deviation) were calculated using the SPSS program version 12.0 (SPSS Inc, Chicago, III). One-way analysis of variance (ANOVA) and post-hoc test (Tukey) were used to compare Holdaway measurements and soft tissue thicknesses among the three groups. Age difference among the groups was also evaluated with ANOVA. Comparison of differences between genders within each group was achieved with the Student's t-test. The level of significance was established at $5 \%$.

\section{Results}

Table 1 shows the demographic data of the patients included to the groups. The groups were statistically well matched on vertical relationships. All groups had corresponding vertical cephalometric measurement (high-angle group, $39.66 \pm 2.14^{\circ}$; low-angle group, $24.72 \pm 2.05^{\circ}$; and normal-angle group, $31.07 \pm 2.37^{\circ}$ ). Age was not statistically significantly different across the three groups.

Student's t-test was used to compare men with women for each group. Table 2 compares the mean and standard deviation of the soft-tissue thicknesses between men and women in each group. Statistically significant differences were found only for the variable basic upper lip thickness, upper lip thickness, Pog, Rhi, $\mathrm{Sn}$, Labiale inferior, labiomentale in high-angle group; for the variables basic upper lip thickness, upper lip

\begin{tabular}{|c|c|c|c|c|c|c|c|}
\hline & \multirow[b]{2}{*}{ Group 1} & \multirow[b]{2}{*}{ Group 2} & \multirow[b]{2}{*}{ Group 3} & \multirow[b]{2}{*}{ p } & \multicolumn{3}{|c|}{ Tukey } \\
\hline & & & & & $I-I I$ & $\mid-I I I$ & II-III \\
\hline Pog & $11.10 \pm 1.92$ & $11.10 \pm 1.87$ & $10.90 \pm 2.11$ & 0.896 & 1.000 & 0.914 & 0.912 \\
\hline Gn & $8.85 \pm 2.30$ & $7.86 \pm 1.43$ & $6.96 \pm 1.63$ & $0.001 * *$ & 0.093 & $0.000 * * *$ & 0.140 \\
\hline $\mathrm{Me}$ & $8.13 \pm 1.88$ & $7.09 \pm 1.42$ & $6.91 \pm 1.81$ & $0.015^{*}$ & 0.051 & $0.020^{*}$ & 0.916 \\
\hline G & $5.83 \pm 0.82$ & $5.62 \pm 0.82$ & $5.52 \pm 1.07$ & 0.881 & 0.998 & 0.888 & 0.914 \\
\hline $\mathrm{N}$ & $6.01 \pm 1.32$ & $5.70 \pm 1.11$ & $5.48 \pm 1.08$ & 0.213 & 0.546 & 0.188 & 0.749 \\
\hline Rhi & $1.79 \pm 0.81$ & $1.66 \pm 0.50$ & $1.48 \pm 0.51$ & 0.151 & 0.692 & 0.129 & 0.484 \\
\hline Sn & $15.16 \pm 2.26$ & $15.13 \pm 2.28$ & $15.04 \pm 2.27$ & 0.977 & 0.999 & 0.977 & 0.986 \\
\hline Sto & $5.54 \pm 1.97$ & $4.36 \pm 1.79$ & $4.08 \pm 1.66$ & $0.006 * *$ & $0.035^{*}$ & $0.007 * *$ & 0.818 \\
\hline $\mathrm{Li}$ & $13.59 \pm 2.27$ & $12.77 \pm 2.25$ & $12.72 \pm 1.69$ & 0.203 & 0.283 & 0.253 & 0.996 \\
\hline Labm & $10.53 \pm 1.29$ & $10.48 \pm 1.48$ & $10.77 \pm 1.48$ & 0.694 & 0.988 & 0.790 & 0.700 \\
\hline \multicolumn{8}{|c|}{ Holdaway measurements } \\
\hline STA & $87.02 \pm 16.78$ & $88.41 \pm 2.65$ & $88.08 \pm 2.81$ & 0.849 & 0.847 & 0.910 & 0.990 \\
\hline $\mathrm{H}$ angle & $12.52 \pm 5.76$ & $13.92 \pm 3.44$ & $14.96 \pm 3.48$ & 0.100 & 0.424 & 0.083 & 0.624 \\
\hline $\mathrm{NP}, \mathrm{mm}$ & $14.67 \pm 3.03$ & $14.60 \pm 2.66$ & $15.36 \pm 2.78$ & 0.511 & 0.994 & 0.611 & 0.542 \\
\hline STSH, mm & $3.32 \pm 2.18$ & $3.27 \pm 2.20$ & $3.95 \pm 2.16$ & 0.406 & 0.997 & 0.502 & 0.450 \\
\hline $\mathrm{ISH}, \mathrm{mm}$ & $5.02 \pm 2.08$ & $4.80 \pm 1.57$ & $3.75 \pm 1.53$ & 0.012 & 0.876 & 0.015 & 0.050 \\
\hline LLH, mm & $1.11 \pm 0.83$ & $0.79 \pm 0.86$ & $1.20 \pm 0.82$ & 0.139 & 0.294 & 0.919 & 0.145 \\
\hline ULT, mm & $11.31 \pm 1.98$ & $11.02 \pm 2.59$ & $10.53 \pm 1.76$ & 0.375 & 0.861 & 0.349 & 0.652 \\
\hline BULT, $\mathrm{mm}$ & $13.52 \pm 2.10$ & $12.84 \pm 2.35$ & $12.51 \pm 2.33$ & 0.221 & 0.473 & 0.204 & 0.842 \\
\hline ULT, mm & $1.53 \pm 1.28$ & $1.19 \pm 0.97$ & $1.29 \pm 0.89$ & 0.448 & 0.434 & 0.656 & 0.933 \\
\hline $\mathrm{SPC}, \mathrm{mm}$ & $1.88 \pm 1.41$ & $1.73 \pm 1.17$ & $2.11 \pm 1.39$ & 0.530 & 0.887 & 0.790 & 0.500 \\
\hline USD, mm & $1.53 \pm 1.28$ & $1.19 \pm 0.97$ & $1.29 \pm 0.89$ & 0.448 & 0.434 & 0.656 & 0.933 \\
\hline \multicolumn{8}{|c|}{$\begin{array}{l}{ }^{*} p<0.05,{ }^{* *}<<0.01,{ }^{* * *} p<0.001 \\
\text { Pog: Pogonion, Gn: Gnathion, Me: Menton, G: Glabella, N: Nasion, Rhi: Rhinion, Sn: Subnasale, Sto: Stomion, Li: Labrale inferior, Labm: Labiomental, } \\
\text { STA: Soft tissue facial angle, NP: Nose prominence, STSH: Soft tissue subnasale to H line, ISH: Inferior sulcus to the H line, LLH: Lower lip to H line, } \\
\text { ULT: Upper-lip thickness, BULT: Basic upper-lip thickness, SPC: Skeletal profile convexity, USD: Upper lip sulcus depth }\end{array}$} \\
\hline
\end{tabular}


thickness, nasion, Rhi, Sn, Sto, labiale inferior in lowangle group; for the variables basic upper lip thickness, upper lip thickness, Pog, $\mathrm{H}$ angle, Nasion, Rhi, Sn, Sto, Labiale inferior in normal angle group between the genders. The thickness values for male were higher in all vertical growth patterns compared with the values for female. Therefore female and male were separately examined for further comparisons.

Table 3 shows norms of Anatolian Turkish adults and comparisons of three studied groups for Holdaway soft-tissue values.

The results of this study showed that, except for four variables, all vertical groups have the same soft tissue norms as reported by Holdaway (Table 3 ).

Table 4 compares the mean and standard deviation of the soft tissue measurements among the studied groups. Four variables (the thickness values at the 'Gn', 'Me', 'Sto' and 'ISH') showed statistically significant differences and higher in low-angle group compared with the values in the high-angle group $(p=0.001,0.015,0.006$ and $p=0.012$, respectively).

The comparison of soft tissue thickness values for women and men are shown in Tables 5-6. Two variables showed statistically significant differences for both women and men. For women, the thickness values at the 'Lower lip-H line' and ' $G n$ ' was found to be statistically significantly higher in the low-angle group $(1.26 \pm 0.86 \mathrm{~mm}$ and $8.95 \pm 2.60 \mathrm{~mm}$, respectively) compared with the values in the normal-angle group $(0.55 \pm 0.53 \mathrm{~mm}$ and $7.45 \pm 1.33 \mathrm{~mm}$, respectively). For men, the thickness value at the 'Nose prominence' in the high-angle group and at the 'Sto' in the low-angle group were found to be statistically significantly higher compared with the values in the normal-angle group.

\begin{tabular}{|c|c|c|c|c|c|c|c|}
\hline & \multirow[b]{2}{*}{ Group 1} & \multirow[b]{2}{*}{ Group 2} & \multirow[b]{2}{*}{ Group 3} & \multirow[b]{2}{*}{$\mathbf{p}$} & \multicolumn{3}{|c|}{ Tukey HSD } \\
\hline & & & & & I-II & I-III & II-III \\
\hline Pog & $10.70 \pm 1.87$ & $10.44 \pm 1.65$ & $10.29 \pm 1.76$ & 0.780 & 0.902 & 0.764 & 0.963 \\
\hline Gn & $8.95 \pm 2.60$ & $7.45 \pm 1.33$ & $6.70 \pm 1.88$ & $0.005^{* *}$ & 0.074 & $0.004 * *$ & 0.494 \\
\hline $\mathrm{Me}$ & $7.81 \pm 2.03$ & $6.68 \pm 1.09$ & $6.52 \pm 1.84$ & 0.055 & 0.128 & 0.067 & 0.958 \\
\hline G & $5.52 \pm 0.95$ & $5.47 \pm 0.79$ & $5.34 \pm 0.79$ & 0.786 & 0.980 & 0.779 & 0.882 \\
\hline $\mathrm{N}$ & $5.58 \pm 1.12$ & $5.28 \pm 0.93$ & $5.24 \pm 0.99$ & 0.549 & 0.651 & 0.572 & 0.993 \\
\hline Rhi & $1.54 \pm 0.40$ & $1.48 \pm 0.40$ & $1.31 \pm 0.43$ & 0.237 & 0.886 & 0.228 & 0.465 \\
\hline Sn & $14.08 \pm 1.47$ & $14.00 \pm 1.72$ & $14.03 \pm 1.97$ & 0.991 & 0.990 & 0.996 & 0.998 \\
\hline Sto & $4.63 \pm 1.70$ & $3.65 \pm 1.50$ & $4.06 \pm 1.86$ & 0.233 & 0.205 & 0.578 & 0.738 \\
\hline $\mathrm{Li}$ & $12.55 \pm 1.88$ & $11.54 \pm 2.02$ & $12.10 \pm 1.24$ & 0.228 & 0.200 & 0.710 & 0.596 \\
\hline Labm & $10.30 \pm 1.06$ & $10.04 \pm 1.56$ & $10.28 \pm 1.40$ & 0.808 & 0.825 & 0.998 & 0.852 \\
\hline \multicolumn{8}{|c|}{ Holdaway measurements } \\
\hline STA & $84.83 \pm 21.48$ & $88.56 \pm 2.58$ & $88.44 \pm 2.56$ & 0.595 & 0.644 & 0.655 & 1.000 \\
\hline $\mathrm{H}$ angle & $12.03 \pm 5.91$ & $12.78 \pm 2.92$ & $14.68 \pm 3.85$ & 0.176 & 0.866 & 0.169 & 0.394 \\
\hline $\mathrm{NP}, \mathrm{mm}$ & $14.63 \pm 3.74$ & $15.11 \pm 2.74$ & $14.69 \pm 2.42$ & 0.872 & 0.882 & 0.998 & 0.905 \\
\hline STSH, mm & $3.08 \pm 1.74$ & $2.83 \pm 1.91$ & $3.49 \pm 2.29$ & 0.601 & 0.927 & 0.807 & 0.579 \\
\hline $\mathrm{ISH}, \mathrm{mm}$ & $4.50 \pm 1.87$ & $4.55 \pm 1.50$ & $3.61 \pm 1.51$ & 0.154 & 0.996 & 0.200 & 0.234 \\
\hline LLH, mm & $1.26 \pm 0.86$ & $0.55 \pm 0.53$ & $1.14 \pm 0.88$ & 0.019* & $0.023^{*}$ & 0.884 & 0.066 \\
\hline ULT, mm & $10.55 \pm 1.93$ & $9.71 \pm 2.45$ & $9.80 \pm 1.45$ & 0.385 & 0.421 & 0.491 & 0.990 \\
\hline BULT, mm & $12.65 \pm 1.64$ & $11.45 \pm 1.82$ & $11.57 \pm 1.73$ & 0.082 & 0.105 & 0.153 & 0.975 \\
\hline USD, mm & $1.44 \pm 1.29$ & $0.98 \pm 0.87$ & $1.26 \pm 1.07$ & 0.458 & 0.430 & 0.873 & 0.723 \\
\hline $\mathrm{SPC}, \mathrm{mm}$ & $1.65 \pm 1.06$ & $1.56 \pm 0.94$ & $1.96 \pm 1.32$ & 0.516 & 0.964 & 0.678 & 0.517 \\
\hline \multicolumn{8}{|c|}{$\begin{array}{l}\text { Pog: Pogonion, Gn: Gnathion, Me: Menton, G: Glabella, N: Nasion, Rhi: Rhinion, Sn: Subnasale, Sto: Stomion, Li: Labrale inferior, Labm: Labiomental, } \\
\text { STA: Soft tissue facial angle, NP: Nose prominence, STSH: Soft tissue subnasale to H line, ISH: Inferior sulcus to the H line, LLH: Lower lip to H line, ULT: } \\
\text { Upper-lip thickness, BULT: Basic upper-lip thickness, SPC: Skeletal profile convexity, USD: Upper lip sulcus depth }\end{array}$} \\
\hline
\end{tabular}


Soft tissue thickness values at the lower anterior face (Pog', Gn', Me') were the lowest in the high-angle group for both women and men.

\section{Discussion}

In the literature, there are few studies with which the pre-and posttreatment and extraction treatment Holdaway soft-tissue measurements can be directly compared. Few studies have also been carried out to assess the soft tissue thickness in adult patients with different vertical growth patterns $(16,17)$. In our study, we also used Holdaway (15) analysis because it presents the soft tissue more in details with simplicity and directness in mind, and it is widely used for evaluation of soft tissue profiles.

The vertical groups included in the study were statistically well matched on gender distribution.
Because statistically significantly greater values were found for soft tissue thickness measurements in male than in female, further comparisons were done separately for women and men to eliminate the effect of gender on findings. In the present study the thickness values for men were higher in all vertical growth patterns compared with the values for the women except for ' $L L H$ ' and ' $G n-G n$ ' in lowangle group and 'Soft tissue angle' in $\mathrm{N}$ group. But statistically significant differences were found only for the thicknesses at Rhi, N, Sto, basic upper lip thickness, upper lip thickness, $\mathrm{Li}$ and $\mathrm{Sn}$ in low-angle group; at Pog, N, Rhi, subnasale, stomion, $\mathrm{H}$ angle, upper lip thickness, BULT and Li in normal-angle group and at Pog, Rhi, subnasale, nose prominence, upper lip thickness, basic upper lip thickness, Li and labiomentale in high-angle group between women

\begin{tabular}{|c|c|c|c|c|c|c|c|}
\hline & \multirow[b]{2}{*}{ Group 1} & \multirow[b]{2}{*}{ Group 2} & \multirow[b]{2}{*}{ Group 3} & \multirow[b]{2}{*}{$\mathbf{p}$} & \multicolumn{3}{|c|}{ Tukey } \\
\hline & & & & & $\mid-I I$ & I-III & II-III \\
\hline Pog & $11.71 \pm 1.90$ & $12.02 \pm 1.81$ & $11.94 \pm 2.34$ & 0.926 & 0.923 & 0.959 & 0.995 \\
\hline Gn & $8.69 \pm 1.87$ & $8.42 \pm 1.43$ & $7.41 \pm 1.01$ & 0.113 & 0.893 & 0.115 & 0.240 \\
\hline $\mathrm{Me}$ & $8.62 \pm 1.58$ & $7.66 \pm 1.66$ & $7.59 \pm 1.61$ & 0.238 & 0.313 & 0.296 & 0.995 \\
\hline G & $5.79 \pm 0.57$ & $5.82 \pm 0.86$ & $5.84 \pm 1.42$ & 0.993 & 0.997 & 0.992 & 0.998 \\
\hline $\mathrm{N}$ & $6.67 \pm 1.38$ & $6.28 \pm 1.11$ & $5.89 \pm 1.15$ & 0.324 & 0.706 & 0.292 & 0.721 \\
\hline Rhi & $2.18 \pm 1.10$ & $1.92 \pm 0.51$ & $1.77 \pm 0.52$ & 0.442 & 0.694 & 0.418 & 0.871 \\
\hline Sn & $16.77 \pm 2.32$ & $16.69 \pm 2.07$ & $16.77 \pm 1.67$ & 0.994 & 0.995 & 1.000 & 0.995 \\
\hline Sto & $6.90 \pm 1.55$ & $5.35 \pm 1.73$ & $4.11 \pm 1.33$ & $0.001 * * *$ & $0.046 *$ & $0.000 * * *$ & 0.144 \\
\hline $\mathrm{Li}$ & $15.14 \pm 1.95$ & $14.47 \pm 1.23$ & $13.80 \pm 1.88$ & 0.186 & 0.591 & 0.160 & 0.611 \\
\hline Labm & $10.88 \pm 1.55$ & $11.09 \pm 1.15$ & $11.63 \pm 1.26$ & 0.391 & 0.913 & 0.375 & 0.592 \\
\hline \multicolumn{8}{|c|}{ Holdaway measurements } \\
\hline STA & $90.29 \pm 3.19$ & $88.20 \pm 2.83$ & $87.44 \pm 3.23$ & 0.083 & 0.222 & 0.083 & 0.819 \\
\hline $\mathrm{H}$ angle & $13.26 \pm 5.69$ & $15.51 \pm 3.57$ & $15.44 \pm 2.84$ & 0.346 & 0.391 & 0.443 & 0.999 \\
\hline $\mathrm{NP}, \mathrm{mm}$ & $14.73 \pm 1.59$ & $13.89 \pm 2.48$ & $16.53 \pm 3.08$ & $0.039 *$ & 0.666 & 0.198 & 0.033 \\
\hline $\mathrm{STSH}, \mathrm{mm}$ & $3.68 \pm 2.76$ & $3.89 \pm 2.51$ & $4.75 \pm 1.72$ & 0.533 & 0.973 & 0.537 & 0.658 \\
\hline $\mathrm{ISH}, \mathrm{mm}$ & $5.80 \pm 2.23$ & $5.15 \pm 1.66$ & $4.00 \pm 1.31$ & 0.065 & 0.645 & 0.055 & 0.268 \\
\hline $\mathrm{LLH}, \mathrm{mm}$ & $0.88 \pm 0.74$ & $1.11 \pm 1.12$ & $1.29 \pm 0.74$ & 0.560 & 0.801 & 0.533 & 0.882 \\
\hline ULT, $\mathrm{mm}$ & $12.45 \pm 1.47$ & $12.83 \pm 1.47$ & $11.80 \pm 1.57$ & 0.258 & 0.800 & 0.565 & 0.231 \\
\hline BULT, mm & $14.82 \pm 2.11$ & $14.76 \pm 1.47$ & $14.14 \pm 2.40$ & 0.669 & 0.997 & 0.696 & 0.730 \\
\hline USD, mm & $1.67 \pm 1.29$ & $1.48 \pm 1.05$ & $1.34 \pm 0.51$ & 0.747 & 0.897 & 0.727 & 0.937 \\
\hline $\mathrm{SPC}, \mathrm{mm}$ & $2.23 \pm 1.82$ & $1.96 \pm 1.44$ & $2.36 \pm 1.53$ & 0.822 & 0.907 & 0.980 & 0.817 \\
\hline $\begin{array}{l}* p<0.05, * * \\
\text { Pog: Pogon } \\
\text { STA: Soft tiss } \\
\text { Upper-lip th }\end{array}$ & $\begin{array}{l}\text { n, Me: Ment } \\
\text { NP: Nose pro } \\
\text { asic upper-lip }\end{array}$ & $\begin{array}{l}\text { labella, N: } \\
\text { e, STSH: Soft } \\
\text { ess, SPC: Skel }\end{array}$ & $\begin{array}{l}\text { hi: Rhinion, } \\
\text { ubnasale to } \\
\text { file convexity }\end{array}$ & Inasale, Stc & $\begin{array}{l}\text { omion, } \\
\text { Ilcus to }\end{array}$ & $\begin{array}{l}\text { e inferior, } \\
\text { LLH: Low }\end{array}$ & $\begin{array}{l}\text { Labiomental, } \\
\text { to H line, ULT: }\end{array}$ \\
\hline
\end{tabular}


and men. According to Uysal et al. (18), statistically significant gender differences were found for the thickness of the labrale superius, labrale inferius, Pog and menton measurements. Celikoglu et al. (17) found that the soft tissue thickness measurements at the lower anterior face for men were higher in all vertical growth patterns compared with the values for the women. In another study they found that all soft tissue thickness measurements in men were higher than those in women (19). However, statistically significant gender differences were not found for all values in each skeletal class (Class I, Class II, Class III). The previous studies (20-22) has shown that the softtissue thicknesses of male patients were significantly greater than those of female patients, although some had no statistically significant difference. In general, women's skin lacks collagen synthesis and facilitates synthesis of hyaluronic acid because of estrogen. In contrast, men tend to have thicker skin because testosterone facilitates collagen synthesis (22). Macari and Hanna (16), except for gender differences in high angle group, found thicker soft tissue in all aspects of the face in men compared with women. The exception in high angle group might be related to the similar effect of the soft tissue at the chin (STC) reduction in subjects with the most hyperdivergence and increased lower face height.

Taki et al. (23) reported that significant differences were found in nose prominence, upper lip thickness, basic upper lip thickness, ISH, and soft tissue chin thickness measurements in comparison of sexes and the soft tissue chin thickness was significantly larger in male than in female. Similar results were obtained by Bascifci et al. (11) who reported that Anatolian Turkish men have a more distinctive chin than women. Conversely Baum (24) found that soft-tissue growth tendencies are different between the two sexes. Baum's (24) studies of children between 11 and 14 years of age indicate that girls develop at an earlier age than boys and tend to achieve a mature adult face earlier. Therefore, in this study to limit growth effects on lip thickness and lip strain, an effort was made to select subjects who have a similar age.

In the literature, few studies $(16,17)$ using conventional lateral cephalometric radiographs and cone-beam computed tomography investigated soft tissue chin thickness in adult patients with various mandibular divergence patterns. In the present study soft tissue facial profile was investigated for different vertical patterns using the Holdaway analysis and soft tissue thickness values.

The $\mathrm{H}$ angle measures the prominence of the upper lip in relation to the overall soft-tissue profile (15). As the skeletal convexity increases, the $\mathrm{H}$ angle must also increase if a harmonious drape of soft tissues is to be realized in varying degrees of profile convexity. Our results showed that the SPC and $\mathrm{H}$ angle were larger than Holdaway norms in group 3, indicating that high angle people have a slightly more convex profile compared with other groups. Also, the BULT and ULT were decreased in all groups in relation to Holdaway norms. Hajighadimi et al. (25) found that Persians have a more convex soft tissue profile compared with Tweed's and Steiner's standards and Taki et al. (23) found that Persian adults have slightly more convex profiles when compared with Holdaway norms. Bascifci et al. (11) found that $\mathrm{H}$ angle showed a significant decrease during the orthodontic treatment and becomes closer to the Anatolian Turkish norms.

The present study aimed to compare the soft tissue thicknesses of orthodontic patients with different vertical patterns. In this study statistically significant differences were found 'Gn', 'Me', 'Sto' and 'ISH' values among the vertical groups when both genders were combined and these were higher in the low-angle group. Whereas statistically significant differences were found for 'LLH' and ' $G n$ ' values in women, statistically significant differences were found for 'Sto' and 'NP' values in men when examined separately. We found that whereas ' $G n$ ' values were the thinnest in the high-angle group, 'LLH' values were the thinnest in the normal-angle group for women and 'Sto' measurements were the thinnest in the high-angle group for men. The thickness measurements at the Gn and menton were thinner in the high-angle group when both genders were combined.

Macari and Hanna (16) evaluated the association between STC thickness and mandibular divergence. They found statistically significantly difference at ' $G n$ ' and 'Me' but not at 'Pog' that suggests the presence of a differential extension between hard and soft tissues during growth. However, the difference for Gn was statistically significant for both women and men when examined separately. The STC thickness apparently adapts to severe hyperdivergence, presumably through increased stretching of the STC in children with progressive increase in facial divergence. 
Celikoglu et al. (17) compared the soft tissue thickness values at the lower anterior face among the adult patients with different vertical growth patterns using cone-beam computed tomography and found that soft tissue thickness values were the thinnest in the high-angle group for both women and men. However, statistically significant differences were found at the labrale superius, inferius, and Pog values for women, whereas the differences among the vertical groups were not significant for the men. In addition, women in the low-angle and normal-angle groups showed similar thickness values.

\section{Conclusion}

Significant differences in soft tissue thickness among vertical patterns were investigated for the gnathion, menton and Sto when both genders were combined. These measurements were thinner in the high-angle group.

Significant differences in soft tissue thickness among vertical patterns were observed for the $\mathrm{Gn}$ in women; for the Sto in men, when examined separately.

Significant differences in Holdaway measurements among vertical patterns were observed for 'inferior sulcus to $\mathrm{H}$ line' when both genders were combined. 'ISH' was thinner in the high-angle group.

Significant differences in Holdaway measurements among vertical patterns were observed for ' $\mathrm{LLH}$ ' in women; for 'nose prominence' in men when examined separately.

In low angle group all soft tissue measurements were greater in men than in women, except for gnathion.

\section{Ethics}

Ethics Committee Approval: This study was approved by the Ethics Committee of Karadeniz Technical University Faculty of Medicine (ethics committee approval no: 2013/91).

Informed Consent: It was taken.

Peer-review: Externally peer-reviewed.

Financial Disclosure: The author declared that this study received no financial support.

\section{References}

1. Fields HW, Proffit WR, Nixon WL, Phillips C, Stanek E. Facial pattern differences in long-faced children and adults. Am J Orthod 1984; 85: 217-23.

2. Opdebeeck H, Bell WH. The short face syndrome. Am J Orthod 1978; 73 : 499-511.

3. Edgerton VR. Neuromuscular adaptation to power and endurance work. Can J Appl Sport Sci 1976; 1: 49-58.

4. Proffit WR, Fields HW, Nixon WL. Occlusal forces in normal- and longface adults. J Dent Res 1983; 62: 566-70.
5. Garner LD. Soft tissue changes concurrent with orthodontic tooth movement. Am J Orthod 1974; 66: 367-77.

6. Ricketts RM. Planning treatment on the basis of facial pattern and an estimate of its growth. Angle Orthod 1957; 27: 14-37.

7. Holdaway RA. Changes in relationship of points $A$ and $B$ during orthodontic treatment. Am J Orthod 1956; 42: 176-93.

8. Burstone CJ. Integumental contour and extension patterns. Angle Orthod 1959; 23: 146-57.

9. Utsuno H, Kageyama T, Uchida K, Yoshino M, Miyazawa H, Inoue K. Facial sof tissue thickness in Japanese children. Forensic Sci Int 2010; 199: 109.

10. Utsuno H, Kageyama T, Uchida K, Yoshino M, Oohigashi S, Miyazawa H, et al. Pilot study of facial sof tissue thickness differences among three skeletal classes in Japanese females. Forensic Sci Int 2010; 195: 165.

11. Bascifci FA, Uysal T, Buyukerkmen A. Determination of Holdaway soft tissue norms in Anatolian Turkish adults. Am J Orthod Dentofacial Orthop 2003; 123: 395-400.

12. Erbay EF, Caniklioğlu CM. Sof tissue profle in Anatolian Turkish adults: Part II. Comparison of different soft tissue analyses in the evaluation of beauty. Am J Orthod Dentofacial Orthop 2002; 121: 65-72.

13. Erbay EF, Caniklioğlu CM, Erbay SK. Soft tissue profle in Anatolian Turkish adults: Part I. Evaluation of horizontal lip position using different soft tissue analyses. Am J Orthod Dentofacial Orthop 2002; 121: 57-64.

14. Kamak H, Celikoglu M. Facial soft tissue thickness among skeletal malocclusions: is there a difference? Korean J Orthod 2012; 42: 23-31.

15. Holdaway RA. Soft-tissue cephalometric analysis and its use in orthodontic treatment planning. Am J Orthod 1983; 84: 1-28.

16. Macari AT, Hanna AE. Comparisons of soft tissue chin thickness in adult patients with various mandibular divergence patterns. Angle Orthod 2014; 84: 708-14.

17. Celikoglu M, Buyuk SK, Ekizer A, Sekerci AE, Sisman Y. Assessment of the soft tissue thickness at the lower anterior face in adult patients with different skeletal vertical patterns using cone-beam computed tomography. Angle Orthod 2015; 85: 211-7.

18. Uysal T, Yagci A, Basciftci FA, Sisman Y. Standards of soft tissue Arnett analysis for surgical planning in Turkish adults. Eur J Orthod 2009; 31: 449-56.

19. Celikoglu M, Buyuk SK, Sekerci AE, Ersoz M, Celik S, Sisman Y. Facial softtissue thickness in patients affected by bilateral cleft lip and palate: a retrospective cone-beam computed tomography study. Am J Orthod Dentofacial Orthop 2014; 146: 573-8.

20. Hamdan AM. Soft tissue morphology of Jordanian adolescents. Angle Orthod 2010; 80: 80-5.

21. Kalha AS, Latif A, Govardhan SN. Soft-tissue cephalometric norms in a South Indian ethnic population. Am J Orthod Dentofacial Orthop 2008; 133: 876-81.

22. Cha KS. Soft-tissue thickness of South Korean adults with normal facial profiles. Korean J Orthod 2013; 43: 178-85.

23. Taki AA, Oguz F, Abuhijleh E. Facial soft tissue values in Persian adults with normal occlusion and well-balanced faces. Angle Orthod 2009; 79: 491-4.

24. Baum AT. Age and sex differences in the dentofacial changes following orthodontic treatment and their significance in treat-ment planning. Am J Orthod 1961; 47: 355-69.

25. Hajighadimi M, Dougherty HL, Garakani F. Cephalometric evaluation of Iranian children and its comparison with Tweed's and Steiner's standards. Am J Orthod 1981; 79: 192-7. 